\title{
Reflections
}

\section{The Place of Music in Qur'anic Recitation}

\author{
Abdurrahman Cetin
}

\begin{abstract}
This paper revisits the debate on the rhythmic recitation of the Quran. It examines the arguments made by those who favor rhythmic recitation and those who oppose it by scrutinizing their Quranic and traditional sources. The paper examines all the ahadith and the Quranic ayahs that relate to the subject and concludes that as long as the rules of tajwid are followed it is permissible to embellish the recitation of the Quran with rhythm as well as modulated voice.
\end{abstract}

It is essential that the Qur'an be recited according to its rules. The Qur'an itself expresses this as tartil, that is, the recitation of the Qur'an in slow, measured rhythmic tones (see verse 73:4). The science of tajwid (a psalmodic reciting of the Qur'an) has its proper method of Qur'anic recitation which has been practiced for centuries. The Prophet Muhammad commanded that the Qur'an be recited in a beautiful way so that its verses are lovingly pronounced in tones of rhythmic music. He esteemed and stimulated those who recited the Qur'an in a beautiful tone.

The question of "chanting" (taghannī) in Qur'an recitation is a question on which there is conflict; in other words, chanting the Qur'an in a rhythmic tone (makām) has become a point of discussion.

As is well known, music has the power to affect the human spirit and penetrate the heart of man. It excites feelings and emotions and sometimes calms; music uplifts the sick, pacifies irritable children, and encourages armies to fight on the battle field. Should music contribute to the recitation of the Qur'an or not? And if so, to what degree?

Before we begin, we must recognize that denying music completely, without any reservation, is not reasonable or realistic, for music and har- 
mony exist both in nature and in man himself. The palpitation of our heart is rhythmic and in perfect harmony. There is music in the flowing of water, in a bird's singing, just as there is music in the crying of a baby and in the moaning of a patient. So it is impossible to separate music from man. What is important is that one should perform it in a halal way.

Everything about Islam is natural; it is the most convenient religion for man. Islam encourages beauty and is not against it. Music is also one of the fine arts, provided man doesn't make it ugly and unpleasant and doesn't perform it in a shameful way.

Every path guiding man to God is halal. Music too is a halal path, if it guides man to Him. If, however, music provokes man to diverge from the straight way of God and blunts his spirit, leading him to sin, fault, and guilt, then it is considered haram.

In addition, music must not be an aim in itself, but a means, it must be used for the benefit of man. Used as a means, one can qualify it according to whether it is being used in a good or a bad way; thus it becomes halal or haram depending upon how it is performed. From this point of view, it is not realistic to categorically reject music and its rhythmic tone.

\section{Narrations on This Matter}

There are many evidences and narrations about reciting the Qur'an with a rhythmic tone. However, it is not fully discussed whether it is allowable or not. Some of these evidences and reports are as follows:

a. God says in the Qur'an: “. . . and recite the Qur'an in slow, measured rhythmic tones" (73:4). In another verse Allah says: “. . . and We have rehearsed it to you in slow, well-arranged stages, gradually” (25:32). In these verses, we are commanded to recite the Qur'an verses slowly, one by one.

In addition to this, in Surah Sad Allah says: "David was given wisdom and sound judgment in speech and decision" (38:20). When David sang in his Psalms (148:7-10), all nature sang to God's glory, in unison with David, and angels, and men of God. "We gave judgment and knowledge; it was our power that made the hills and the birds celebrate our praises with David. It was We who did all these things" (21:79). Therefore, the words of the Qur'an must not be read hastily, merely to get through so much reading. They must be studied, and their deep meanings pondered over. They are themselves so beautiful that they must be lovingly pronounced in tones of rhythmic music. 
b. Qatāda narrated: I asked Anas bin Mālik about the Prophet's recitation. He said, "He used to prolong (certain sounds very much)."1

c. Abdullah bin Mughaffal narrated: I saw the Prophet reciting the Qur'an while he was riding on his she-camel or camel which was moving, carrying him. He was reciting Surat al-Fath or part of Surat al-Fath very softly and in an attractive vibrating tone. ${ }^{2}$

Shu'ba narrated: Muawiya bin Qurra reported that Abdullah bin al-Mughaffal al-Muzani said, "I saw Allah's Messenger on the day of the Conquest of Makkah, riding on his she-camel and reciting Surat al-Fath or part of Surat al-Fath. He recited it in a vibrant quavering tone." Then Muawiya recited as Abdulah bin al-Mughaffal had done and said: "Were I not afraid that the people would crowd around me, I would surely recite in a vibrant quavering tone as Ibn al-Mughaffal did, imitating the Prophet. I asked Muawiya, "How did he recite in that tone?" He said thrice, "A, A, A." 3

Some people say that the $\operatorname{tarji}$ in the recitation of the Prophet came from the movement of the camel on which he was riding; but it is very difficult to say if this is right, because if it is so, that is to say, a changing of sound, it would be, surely, discerned by the Companions of the Prophet and then the narration above would make no sense.

d. Mut'im narrated: I heard the Prophet reciting Surat Tur in the Maghrib prayer, and when he reached the verse "Were they created by nothing, or were they themselves the creators, or did they create the Heavens and the Earth? Nay, they have no firm belief nor do they own the treasuries of Your Lord, nor have they been given charge (there of)?" (59:36) my heart was about to fly (when I realized this firm argument). ${ }^{4}$

In another narration, he said that after he had listened to the Prophet's recitation, he didn't hear anyone who did a better recitation than him and who had a more pleasant tone than him. ${ }^{5}$

e. Barā b. Azib narrated: I heard the Prophet when he used to pray the 'Isha prayer, he was reciting Surat al-Tur, I didn't hear anybody who had better recitation than him or who had a more pleasant sound than him. ${ }^{6}$

f. Barā b. Azib narrated: The Prophet said: "Embellish the Qur'an with your sound." "7

Though some people pretended that this hadith means "Embellish your sounds with the Qur'an," the following hadith doesn't lead to such a meaning: "Embellish the Qur'an with your sounds, for a nice sound increases the attractiveness of the Qur'an."8 
g. Abu Huraira narrated: The Prophet said, "Allah does not listen to a prophet as He listens to a prophet who recites the Qur'an in a loud and pleasant tone." Sufyan said, "This saying means: a prophet who regards the Qur'an as something that makes him dispense with many worldly pleasures."9

h. The Prophet had heard Abu Musa one night reciting the Qur'an; the next morning he said to him: "O Abu Musa! You have been given one of the musical wind-instruments ${ }^{10}$ of the Family of David." 11 "If I had known that you had been listening to my recitation, I would have made better my recitation for you, and would have embellished it," said Abu Musa. ${ }^{12}$ Ibn Kathir said that this hadith proves that embellishing the recitation of the Qur'an and working for this is a religious duty. ${ }^{13}$

i. Abu Huraira narrated: The Prophet entered the mosque and heard a man reciting the Qur'an and asked: "Who is this man?" "This is Abdullah bin Kaiss," they said. The Prophet then said, "Indeed, this man had been given one of the melodies of the Family of David." 14

j. Jabir narrated: The Prophet said: "The best reciter of the Qur'an is the man who, when he recites the Qur'an, you believe is the most fearful of God."15

k. Abu Salama narrated: Abu Huraira said: Allah's Messenger said, "Whoever does not recite the Qur'an in a nice voice (taghannī) is not from us." And others added, "(that means) to recite it aloud."16 This hadith was also narrated by Sa'd b. Abu Wakkas from Aisha from Abdullah b. Abbas and Abu Lulala. ${ }^{17}$

Ibn Abi Mulaika was asked: "If someone doesn't have a nice voice, what about him?" He replied as follows: "He tries to make it as nice as he can."18

About the term of taghanni (a nice voice) mentioned above, there are different commentaries and interpretations, many of which are not accurate. Some of them are as follows:

1. The term of taghanni (a nice voice) above mentioned in the hadith is in the sense of tartil and tajwid. It means to recite the Qur'an according to the rules of tajwid and tarfil and by embellishing the voice as far as possible. Whoever doesn't recite the Qur'an as it was said above, that is to say, in a nice voice, is not from us. In our opinion, this is the most reasonable view of all. As it is known, a nice voice is a gift of Allah. Taghannī (chanting with a nice voice) is something related to talent. From this point of view, "Whoever does not recite the Qur'an with a nice voice and with a change of tune (naghma) is not from us." Understanding the hadith in this way is not true. Such 
an understanding means to punish most of the Muslims. It should be added that there is no restriction on this matter in the hadith, only that reciting the Qur'an is a merit (sawab) in God's sight. As it was said above, this hadith was recommended to pay close attention to the reciting of the Qur'an.

2. Taghanni means reciting the Qur'an with a loud and intelligible voice.

3. It means reciting the Qur'an with a pathetic and sorrowful voice. As it was understood then, those who do not recite it like that will be left apart; this view is not admissible either.

4. It means "advantage." It means that whoever does not take advantage of the Qur'an is not from us. This sense is true, but it does not lead to this hadith, so it cannot be taken seriously.

5. It means "occupation." Whoever is not occupied with the Qur'an is not from us. But this interpretation was not accurate either and it was not taken seriously.

6. It means "to dispense with the need" (istighna). It means whoever does not dispense with the need of the Qur'an is not from us. That is to say, whoever is not contented with the need of the Qur'an is not from us. This is the most well-known analogical interpretation (ta'wil) which turns the hadith from its aim. But many scholars, like Imam Shafi'i and Tabari, were opposed to this view. Tabari explained, by giving examples from Arabic poetry, that such an interpretation of this hadith could never be in conformity with the Arabic language. ${ }^{19}$ Equally Imam Shafi'i said that taghannī did not mean to dispense with the need of something. ${ }^{20}$

Even though the term taghannī means to recite the Qur'an with a rhythmic tone (makām), there are some points to be emphasized that follow along with it. As one recites the Qur'an with a rhythmic tone (makäm), one must never give up the rules of tajwid. It is not permissable to pronounce a letter with a long vowel where it isn't appropriate, or not to pronounce a letter with a long vowel where it is appropriate; to omit some letters, as an ellipsis, from a word or some words in a sentence, or to add some. It may be that those who do not recite the Qur'an with a rhythmic tone (makäm) may suspect this point. As a matter of fact, someone had asked Ahmad bin Hanbal about reciting the Qur'an in a melodious air (alhän); thereupon the Imam asked him what his name was. He replied "Muhammad." "If you 
were called "Mu-ham-mad," would you like it?" asked the Imam. So he did translate his ideas about that question. ${ }^{21}$ However, it is not appropriate to detain the audience by reciting with an unnecessary melody.

On the other hand, there are narrations concerning the contrary. Some are as follows:

a. Huzaifa narrated: Allah's Messenger said: "Recite the Qur'an with a melodious Arabic air (alhän) and with their voice; beware of the melodious air of men of debauchery and of the men of the Book (the Jews and the Christians). After me there will come such a group that reads and recites the Qur'an with the melody of songs and like the tarji (a sort of attractive vibrating tone) of clergy and of those who cry on deeds. Their way of recitation does not come down from their throat. Their hearts and the hearts of those who envy them are troubled." 22

This narration which is rather well known and was narrated by Tabarani and Bayhaqi from Abu 'Ubayd Kasim b. Sallam was not estimated as "authentic" by a great number of scholars.

Ibn al-Jawzi said that this report ( $k h a b r$ ) is not authentic. Zahabi said that it is "indeterminate" (munkar). Haysami reported that one of the narrators (rawi) mentioned in the transmission (sanad) is unknown. ${ }^{23}$

Alauddin Ali Riza, who edited Al-Wajiz of Kurtubi, points out that the person named Bakiyya b. Walid mentioned in the transmission of the hadith is mudallis ${ }^{24}$ and that the person named Shaykh Abu Muhammad is "unknown"; ${ }^{25}$ so this narration is "invalid"26 (ma'lul) for two reasons.

If this hadith was said by our Prophet we would be delighted to admit it; however, it is doubtful that he said it. There are weaknesses in its transmission (sanad) and vagueness in its sense. Our Prophet had extended facilities about reading or recitation of the Qur'an in his hadith of "Seven letters." ${ }^{27} \mathrm{He}$ could not have said that non-Arabic people should recite the Qur'an with impeccable Arabic and harmony. Furthermore, his companions were originally Arab, so why should he say to them, "Recite the Qur'an like an Arab." Besides, a part of this hadith is opposed to another hadith, which is as follows: "While you recite the Qur'an weep, if you cannot do so, try to weep."28

Since the Qur'an is in Arabic, it may be reasonable to say that one should recite it as an Arab, but on the other hand, every community has its proper way of recitation, and this point of view should also be admitted. The main principle or the essential rule of recitation of the Qur'an is the tajwid, and 
then comes the Arabic tone. We know that some Arab reciters don't follow the rules of tajwid.

b. Ibn Abbas narrated: Allah's Messenger had a mu'adhdhin who was pronouncing the adhan by changing, moving, and vibrating his voice (tatrib). The Prophet said to him: "The adhan is regular and simple, if your adhan will be regular and simple pronounce it, otherwise don't pronounce it." 29

This narration is not authentic (sahih). Zahabi said that it was indeterminate (munkar).$^{30}$ In fact, such a statement doesn't match with the teaching and guiding style of the Prophet.

Though the two above mentioned narrations are brought as evidence by those who are against the recitation of the Qur'an with a rhythmic tone (makām), it has been proven that they cannot stand as evidence against the view that permits beautifying the recitation of the Qur'an.

\section{Related Views and Their Appreciation}

There are generally two views about the recitation of the Qur'an with a rhythmic tone:

a. Anas b. Malik, Said b. Musayyab, Said b. Jubair, Hassan Basri, Ibrahim Nehai, Ibn Sirin, Imam Malik, and Imam Ahmad b. Hanbal were against the recitation of the Qur'an with a rhythmic tone. ${ }^{31}$

Their evidence was the last two narrations mentioned. They maintained that the rhythmic tone could not only change the pronunciation, but also dismiss the thought or the meaning.

Those who were against the recitation of the Qur'an with a rhythmic tone expressed their views as follows: "The recitation with taghanni means changing the meaning of the words, and turning the vowels (haraka) because of their prolongation-into letters. The recitation of the Qur'an with taghanni and reading it in a manner such as the letters and the vowels are changed is not halal. Such a reading because of abundance of voice and melody is not understood by the audience or by the listeners of the Qur'an. One must not listen to those who do so. The taghannī that alters or adds or reduces letters is haram. Both readers and listeners become sinful. If the taghannī were allowed, an endless liberty of melody would be given. From then on, some people would recite the Qur'an as they sing. To prevent this means opposing the ways leading to the haram. Tatrib and tarji are not halal during the recitation of the Qur'an, because it causes the recitation to resemble the melody and change of tune (naghma) made by the people of 
wickedness ( $a$ hl fisq). It is not halal to recite the Qur'an with the melody and the change of tune, for the Qur'an is exempt from this kind of recitation."

According to the narration, Abdullah b. Omar had prevented his son from reciting the Qur'an with an air of melody (alhän). ${ }^{32}$

b. Hadrat Omar, Abdullah b. Mas‘ud, Abdullah b. Abbas, Imam Abu Hanifa, Imam Shafi'i, Tabari lbn al-Arabi and those like them said that the recitation of the Qur'an with the makäm is halal. ${ }^{33}$

It is related that when 'Umar ibn al-Khattab saw Abu Musa imitating the style of recitation of the Prophet he said to him, "Remember us our Lord!" Thereupon, he began to recite the Qur'an. ${ }^{34}$ Once more, he had asked Uqba b. Amir, who had a good voice, to read a surah of the Qur'an. When he was reciting, Hadrat 'Umar broke down into tears. He then said, "I thought for sure that it had just descended from heaven!" 35

The hadiths mentioned above prove this view, except for the last two.

Those who admit this view suppose the following points: Recitation of the Qur'an by embellishing the voice according to the religious measures and in accordance with the rules of tajwid means respecting the religious principles. Our Prophet too had made tarjl. Abu Musa said to the Prophet, "If I had known that you were listening to my recitation, I would have made my recitation better for you, and I would have embellished it." This narration is evidence for the embellishment of the voice. It is then halal to try to recite better and to try to embellish the voice. A recitation which provokes listeners to break into tears, and is within the rules of tajwid, is good and pleasant (mustahab). The souls are more inclined to the readers with rhythmic tone than to the others who don't recite it with rhythmic tone, because the rhythmic tone and the melody are effective on the heart. In order to say that something is haram, it should be forbidden by a final judgment. The fact is that there is no final judgment about the recitation of the Qur'an. Recitation of the Qur'an with a rhythmic tone (makäm) neither changes the pronunciation of words nor prevents the understanding of their meanings. However, melodies which are contrary to the rules of tajwid are of course haram. Yet, by respecting the rules of tajwid, embellishing the voice is halal because a good voice doubles the goodness of the Qur'an. ${ }^{36}$

In our opinion, what leads these two groups to two different results is their separation in the conceptions of rhythmic tone (makäm).

The main worry of the first group is that one may recite the Qur'an just as he sings a song, as Imam Malik points it out. They fear that by doing so, 
the sublime words of the Qur'an might be changed. As a matter of fact, as we transmitted above, the answer of Ahmad b. Hanbal "If you have been called "Mu-ham-mad," would you like it?" asserts what we are saying.

Yet, we must admit that even those who allow the recitation of the Holy Qur'an with a rhythmic tone don't tolerate possible mistakes during the recitation. For them the Qur'an could not be made similar to a song; neither could the negligence or the nonobservance of the rules of tajwid be tolerated.

Those who are against the rhythmic tone (taghanni) could not allow such a probability. One should respect this. As a matter of fact, there have been people who preferred the rhythmic tone to the rules of tajwid. The most famous example is seen during the recitation of the Qur'an by those who recite poetry in commemoration of the birthday of Mohammad. This kind of recitation is always haram, unless it is in accordance with the rules of tajwid. In our opinion, as we possess a safe and sure measure like the tajwid, such inconvenient recitations can always be prevented.

Concerning this matter, there is another important point. As it can be easily seen, there is an incomparable harmony and music in the Qur'an itself. One may find this harmony in the recitation of anyone who is sure of the Qur'an he recites. Some writers have studied the Qur'an from this point of view and have concluded that the Qur'an can be related in a large sense to music. Surah Rahman is a good example. It is sufficient for readers to remember only this surah. ${ }^{37}$

\section{Conclusion}

The Qur'an has been studied by Muslims from all points of view: Its reading, its recitation, its interpretation, and its commentaries. The reason is that Muslims have had an extreme and endless respect for the Qur'an for centuries.

The recitation of the Qur'an has been established by both sciences of qira'at (readings) and tajwid. Yet, the matter of music in the recitation of the Qur'an has always been a question of discussion. In other words, the discussion was based on the rhythmic tone.

As it is known, the religion of Islam being a natural one, it is the most convenient religion for humanity. As for the human being, he is fond of beauty and of that which is beautiful. As to music, it is the oldest, the most expanded, and the most effective of all fine arts. From this point of view, 
one cannot be against music, provided that it is performed and used in a positive and halal way.

It should be added that the meaning of the verses and hadiths mentioned in our article show that, on condition that one respect the rules of tajwid, it is halal to embellish and to beautify the recitation with a good voice and with a rhythmic tone. However, it is not halal to make a show. One should not forget that the Qur'an contains God's words and that the recitation of the Qur'an is an act of worship.

\section{Glossary to Recitation of the Qur'an}

Music: The art of putting sounds together in order to express feelings and thoughts. The science of arranged and measured sounds. The art of making pleasing combinations of sounds in rhythm, harmony, and counterpoint; the sounds and composition so made; written or printed signs representing these sounds. ${ }^{38}$

Makām (rhythmic tone): A regular succession of weak and strong stresses, accents, sounds or movements in music. ${ }^{39} \mathrm{~A}$ series of musical notes that form the main part of a piece of music. ${ }^{40}$

Lahn (tune, air): This term has two contrary meanings: (1) Tune, air, melody, chant, song, melodiousness, euphony, interlude, well-accorded sound. (2) To make mistakes in the reading or reciting of the Qur'an. To be wrong and inaccurate in the sense of verses or about the rules of the science of tajwid, psalmodic reciting of the Qur'an. In addition to these meanings, this term means to speak in such a manner that others cannot understand. ${ }^{41}$ In the Qur'an, this term is used in the sense of "tone of speech." ${ }^{42}$ In the science of tajwid, the mistakes which are made in the essence and attributes of letters are called lahn.

Tartīl (reciting in a slow, measured tone): This term means pronouncing the words in a good and convenient manner properly using it in its place. ${ }^{43}$ In Qur'anic terminology it means recitation in slow, measured rhythmic tones. It is a term of the science of tajwïd.

Taghghanni (chanting): Saying the word with tune and melody in a rhythmic tone. Additionally, it means being rich and wealthy; in poetic language, it means satirizing and flattering. ${ }^{44}$ The word is used by the Prophet Muhammad, but among people it has been used in a negative sense.

Tarji (reciting in an attractive, vibrating tone): Returning, going back, giving a trembling sound, and repeating it in the throat. ${ }^{45}$ 
Tahzinn: Being pathetic and sorrowful with a gloomy or melancholic expression, being very grieved during the recitation, almost in tears. ${ }^{46}$

Tatrib: Moving and vibrating of sounds on the pitches of the voice; and rendering the song more pleasant and more agreeable. It also means prolonging long as well as short vowels. ${ }^{47}$

Tarkis (make oscillate or swing): Oscillating or vibrating of sounds during recitation; also emphasizing with vowel point and vocalizing letters. ${ }^{48}$

Tar'i d: Vibrating of sounds during recitation. ${ }^{49}$

Tarannum (singing psalms): Playing and singing, trilling or humming pleasantly and with harmony. The singing of the nightingale. ${ }^{50}$

\section{Notes}

1. Sahih al-Bukhari, The Book of the Virtue of the Qur'an 29 (Translated by Dr. Muhammed Muhsin Khan), VI, 512.

2. Ibid., 513

3. Sahih al-Bukhari, Tawheed 50, IX, 474.

4. Sahih al-Bukhari, The Book of Commentary, Surat al-Tūr, 377, VI, 357.

5. Ibn Kathir, Fadä'il al-Qur'an (The Virtue of the Qur'an), 36.

6. Al-Bukhãri, Ad̆han (The Call to Prayer), 102, I, 186.

7. Ibn Māja, Iqãma, 176; Abu Dãwud, Vitr 20.

8. Dārimì, Fadä'il al-Qur'an (The Virtue of the Qur'an), 34.

9. Al-Bukhari, The Book of the Virtue of the Qur'an 19, VI, 500.

10. The musical instruments stand here for the nice voice.

11. Al-Bukhari, The Book of the Virtue of the Qur'an 31, VI, 514.

12. Ibn Kathir, Fadā'il al-Qur'an, 35.

13. Ibid.

14. Muslim, Salat al-Musafirin, 235.

15. Ibn Maja, Iqāma 176; Darimi, Fadâ'il al-Qur'an, 34; Bayhaqi, As-Sunanu'l-Kubra, II, 388.

16. Al-Bukhari, Tawheed 44, IX, 464.

17. Ibn Kathir, Fadä'il al-Qur'an, 38.

18. Qurtubi, Al-Wajiz, 55; Ibn Kathir, Fadà’il al-Qur'an, 38.

19. Qurtubi, Al-Wajiz, 59; Ibn Qayyim al-Jawzi, Zad al-Ma'ad, I, 135.

20. Bagawi, Sharh al-Sunnah, IV, 486: Qurtubi, Al-Wajiz, 59; Ibn Kathir, Fadāill alQuran, 34.

21. Ibn Qayyim al-Jawzi, Zad al-Ma'ad, I, 135.

22. Bayhaqi, As-Sunanu'l-Kubra, II, 540; Qurtubi, Al-Wajiz, 66; Hindi, Kanz al-Ummal, I, 606

23. See Munawi, Faid al-Qadir, II, 65-66.

24. The term mudallis means a man who has narrated a hadith from someone, though he hasn't really heard it from him; so it is as though his report is not valid (Talat Kocyigit, Terminology of Hadith, 251).

25. His identity or his reliability is not well known.

26. Qurtubi, Al-Wajiz, 67, footnote 56.

27. For further information about this matter, see A. Cetin, Qur'an-i Kerim'in Indirildigi Yedi Harf (Seven Letters by which the Qur'an has been Descended), Precis edition: Islami Arastirmalar, s. 3 (1987).

28. Ibn Maja, Iqama, 176.

29. Daraqutni, as-Sunan, I, 239.

30. Zahabi, Midhan al-l'tidal, I, 205.

31. Ibn Hagar al-Asqalani, Fath al-Bari, IX, 64. 
32. Bayhaqi, As-Sunanu'l-Kubra, II, 18.

33. Ibn al-Jawzi, Zad al-Ma'ad, I, 135.

34. Ibn Sa'd, Tabaqat, IV, 109; Ibn al-Jawzi, Zad al-Ma'ad, I, 135; Ibn Kathir, Fadā'il al-Qur'an, 35.

35. Ibn al-Jawzi, Zad al-Ma'ad, I, 135.

36. See Ismail Karacam, Qur'an-i Kerim'in Faziletleri (The Virtues of the Qur'an alKarim), 130.

37. See for this matter Tayyib Okic, Kur'an-i Kerim'in Uslup ve Kiraati (The Style and the Recitation of the Holy Qur'an), 13; Muhammed Hamidullah, The History of Holy Qur'an (Qur'an-i Kerim Tarihi), 92.

38. See Turk Dil Kurumus Turkish Dictionary, II, 867; Meydan Larousse, IX, 183; Mehmet Dogan, A Big Turkish Dictionary, 717; Oxford Advanced Learners Dictionary, 557; The Colombia Encyclopedia, 1346.

39. Oxford, 929.

40. Collings Cobuild English Language Dictionary, 1570.

41. See Ragib, Al-Mufradãt, 449; Jawhari, as-Sihāh, VI, 2193; Abu'l-Baka, Al-Kulliyyāt, 319; Asim Efendi, Dictionary Translation, IV, 746; Ibn Manzūr, Lisān, XIII, 379; Zamakhshari, Asäs al-Balagha, 562.

42. "... and you should have known them by their marks, but surely you will know them by the tone of their speech!" $(47: 30)$

43. Asim Efendi, Dictionary Translation, 1313.

44. Ibid., III, 1111.

45. Ibid., III, 258.

46. Ibid., IV, 588 .

47. Ibn Manzūr, Lisan, XIII; Asim Efendi, Dictionary Translation, I, 356.

48. Suyūî, Al-Itqā̄, I, 102.

49. Ibid.

50. Asim Efendi, Dictionary Translation, IV, 317 . 